\title{
Ranking Laptop Brands in Iran Using Gray Data Analysis According to Brand Value Criteria
}

\author{
Mahdieh Rostami ${ }^{1}$, Mir Taher Porpartovi ${ }^{1 *}$, Seyed Mohammad Javadi ${ }^{1}$ \\ ${ }^{1}$ Department of Management, Buinzahra Branch, Islamic Azad University, Buinzahra, IRAN
}

*Corresponding Author: Taher_Porpartovi@yahoo.com

Citation: Rostami, M., Porpartovi, M. T. and Javadi, S. M. (2017). Ranking Laptop Brands in Iran Using Gray Data Analysis According to Brand Value Criteria. Dutch Journal of Finance and Management, 1(2), 41. https://doi.org/10.29333/djfm/5817

Published: April 12, 2017

\begin{abstract}
Brand is among the determinants of purchase, especially in the laptop market. Brand or trademark introduces and represents products. In the business world, brands have material value and are priced. In some cases, the pricing is more valuable than tangible assets of organizations, since brands create competitive advantage in the business world. There are various ways to valuate brands, most of which focus on pricing. However, the present study discussed the ranking of laptop brands available in Iran's market using the multi- decision-making criteria based on the gray analysis. In doing so, certain data were collected from laptop sales representative in Iran. The analysis included Brands of Apple, VAIO, Samsung, Lenovo, Asus, Toshiba, MSI, HP, Dell, and Acer.
\end{abstract}

Keywords: brand value, multi-criteria decision-making, Gray data analysis, Iran's laptop market

\section{INTRODUCTION}

Brand is one of the crucial factors in the development of the product in the market. In the electronic products market, especially the laptop market, brand is a crucial determinant of buyers' decision-making. In addition, customers' view to brands is heavily crucial on market value and brand equity in the market. In competitive markets, brand loyalty entails numerous advantages such as building barriers for competitors, greater sales and revenue, reduction of customer absorption costs and control of customers' sensitivity to competitors' marketing efforts. Nowadays, brands play a major role in improving consumers' life and increasing value for companies. Brands introduce the basis as well as the major manufacturer of the product and allow the consumers to ask for accountability and responsibility from the manufacturer or the supplier. The customer may sometimes value two similar products based on the banding approach differently. Along with people, experiencing more complicated and busier life as well as shortage of time, brand value increases growingly because of simplifying the purchase decision and decreasing the risk thereof. Brands offer signals of quality to make the purchase decision easier. Brands may help with quality assessment depending on the product type. Therefore, given the importance of branding, the pertinent influence on the valuation of products could be realized. Thus, the present study investigates the factors influencing on such valuation.

All customer touch points with a brand provide an opportunity to create a good attitude and increase brand loyalty. The key among them is sales behavior). Since the seller is often the only person to have contact with customers, he or she can have a vital role in the customer experience and evaluation of the brand. In modern marketing research, it is claimed that market researchers need to fully understand the consumer behavior in order to adopt an appropriate basis for strategic decisions in the target market as well as constructing a position for the 
product. It may be noted that one of the most valuable assets of any company for increasing the productivity of marketing programs, is to have a brand created in the mind of the consumer because of those marketing programs. In recent years, intangible assets including the company's brand have enjoyed from extraordinary importance for companies. Such assets are included among vital factors affecting generation of value and even the company's sustainability. From the market's perspective, one of the key advantages of brand evaluation will be the effect made on making the best decision on goods and services by increasing the consumer information.

On the other hand, one of the important issues for companies is to find the impact of their efforts and planning for the success of the company. Such efforts as advertisement, after sales service and alike are in fact kinds of longterm investment (Barth et al., 2012; Fornell, 1983; Jinfeng, 2009). Thus, although the impact of costs that will be spent for raising the company's brand is visible in the long term, the evaluation of the adequacy of such activities for the company's management is of high importance. Since brand recognition refers to people's mentality in relation to the brand, it should be understood that what factors are formed in the mind of potential and actual customers which make a particular product with a brand more valuable than another brand or a product without a brand (from the customers' view)? Alternatively, what makes a brand valuable for the organization?

A wide range of research has been carried out on ranking of brands based on various models. In the following, some of the seminal ones will be discussed. For decision-making and ranking of brands, it is necessary to use decision-making criteria definition. Decision-making criteria used in this study are defined as follows.

- Perceived Quality: Perceived quality means customer judgments about the importance of brand dimensions and preference or advantage that make the customer choose to buy a good product or service (Aaker, 1996; Atilgan, 2005; Crocker, 1986).

- Brand awareness: It includes customer diagnosis, recall, awareness, knowledge area and retention. Brand awareness makes it effect through influencing the brand power consistency with customer decision-making. Brand awareness involves information that an organization's brand presents through advertisement, facilities, appearance of services providers, and the name and mark of organization.

- Brand equity: It is supported via mental association, consumer's form of the brand in their minds. Association of brand that establishes brand identity refers to everything directly or indirectly associated with to the mind of the customer. Association of brand could be categorized as follows. An asset can create distinctive reasons for purchase, affects feelings of a certain product and extends the basis of the brand. Some associations influence purchase decisions through giving credibility and confidence to a brand, some provoke positive feelings and then transfer the feelings to the brand.

- Brand loyalty: One of the major assets of brands is brand loyalty in which a number of conceptual frameworks of brand equity are overlooked. However, there at least two reasons confirming the inclusion of brand loyalty within the conceptual framework of brand equity. First, brand equity for a company is mainly obtained from customer loyalty to the brand. In valuation of brands for the purpose of sales and purchase, brand loyalty should be considered as a key factor, because a base of loyal customer of can entail a flow of sales and profit for the brand owner. A loyal customer may spend more money to have a brand because he or she observes some values exclusive to the products of a brand absent in alternative options. Second, attention to loyalty, as an asset, leads to plans focusing on increasing loyalty that will increase brand equity peers.

They concluded that store brands could affect retailers' mental image of brands, since these brands are of great importance for retailers who are actively developing store brands programs for the future ten years. Ratnatunga and Ewing (2009) presented an approach for estimating brand capacity. They suggested that there are many academic and financial measures for estimating the value of a brand. Managers often use these measures when they want to buy or sell a brand. The old approach to estimates the brand value is the well-known interbred approach. In this study, the interbred approach was developed so that it could help managers for brand evaluation. Budac and Baltador (2013) reviewed brand evaluation methods. They stated that brand equity is a strategic advantage for companies, and a successful brand management should focus on the capital value of its brand. In general, they concluded that the objective of brand management is to strengthen the company's brand equity so that the company's brand could be easily identifiable and recognizable to the public. However, little information exists on the effect of such variations on stock returns. The researchers attempted to examine the effect of brand value on stock price. Data on 503 brand value announcements between 2001 and 2012 was examined. Cross-sectional regression analysis was used to analyze the data. The results revealed mixed effects of brand value announcements on stock returns. In addition, it was suggested that companies' size also affects stock returns. The result indicated that loyalty to chain stores private brands products (number of purchase) and the fact that people are actively looking for chain stores private brands are primarily motivated by the perceived value of money. Theoretically, it is defined as maximizing the advantages (positive characteristics) earned by the individual for the amount of money she pays. It was also revealed that perceived quality has less effect than perceived value of money on purchase behavior. The results suggested that the number of customers who were satisfied with products with private labels 
because of quality and the store's support of those products were higher than the number of customers who were satisfied with those products because of lower costs than competitors'.

\section{METHODOLOGY}

The gray theory proposed by Deng in 1982, is among the mathematical concepts mostly used in multi-criteria decision-making. The theory is very effective in dealing with uncertainty problems with unknown or incomplete information. In general, information related to decision makers' preferences on different criteria and reasons are expressed based on their qualitative judgment. In practice, decision makers' judgments are often unreliable judgment, and are not expressible within precise numerical values. The gray theory is applied for the study of uncertainty of and incomplete information. Its use in the analysis of mathematical systems with incomplete information is growing increasing. The main components of the gray analysis include gray prediction, gray relational analysis (GRA), gray decision, gray planning and gray control. To understand the issue a distinction should be made between two fundamental concepts: Gray Logic: Gray System and Gray Numbers. The issue of gray logic is a quantitative approach based on gray numbers in resolving various issues. The approach could be generalized to solve quantitative problems including multi-criteria decision-making. For example, gray DEAMATEL or number-based gray network analysis and gray calculation are explainable. The gray relational analysis or GRA is only a multi-criteria decision-making technique with particular rules and principles which is not necessarily solved with gray numbers. Thus, the GRA technique and gray logic should be distinguished.

\section{Gray System}

If clear and well-known information of a system are visualized with white and unknown information with black, then information of systems in the nature are not white (well-known) or black (unknown) information, but are a mixture of the two colors, i.e. gray. These are called gray systems, the main characteristic of which is the lack complete of information about the system.

\section{Gray Numbers}

Each gray system is described by gray numbers, gray equations and gray matrices. Gray numbers are considered as atoms or cells of the system. A gray number could be defined with verbal variables which are expressed with numerical intervals. These numerical intervals include uncertain information. In other words, gray numbers refer to numbers with uncertain values, but a certain interval. A gray number could be defined as follows:

$\otimes \in[a, b]$

Let two gray numbers as follows. Then:

$$
\begin{aligned}
& \otimes_{1} \in[\mathrm{a}, \mathrm{b}], \otimes_{2} \in[\mathrm{c}, \mathrm{d}] \\
& \otimes_{1}+\otimes_{2} \in[\mathrm{a}+\mathrm{c}, \mathrm{b}+\mathrm{d}] \\
& \otimes_{1}-\otimes_{2}=\otimes_{1}+\left(-\otimes_{2}\right) \\
& -\otimes=[-\mathrm{b},-\mathrm{a}] \\
& \otimes^{-1} \in[1 / \mathrm{b}, 1 / \mathrm{a}] \\
& \otimes_{1} \in[\mathrm{a}, \mathrm{b}], \otimes_{2} \in[\mathrm{c}, \mathrm{d}] \\
& \otimes_{1} \times \otimes_{2} \in[\min \{\mathrm{ac}, \mathrm{dd}, \mathrm{bc}, \mathrm{bd}\}, \max \{\mathrm{ac}, \mathrm{ad}, \mathrm{bc}, \mathrm{bd}\}] \\
& \otimes_{1} / \otimes_{2}=\otimes_{1} \times\left(\otimes_{2}\right)^{-1} \\
& \otimes_{1} / \otimes_{2} \in[\min \{\mathrm{a} / \mathrm{c}, \mathrm{d} / \mathrm{d}, \mathrm{b} / \mathrm{c}, \mathrm{b} / \mathrm{d}\}, \max \{\mathrm{a} / \mathrm{c}, \mathrm{a} / \mathrm{d}, \mathrm{b} / \mathrm{c}, \mathrm{b} / \mathrm{d}\}] ; \mathrm{cd}>0 \\
& \mathrm{~K} \times \otimes_{1} \in[\mathrm{ka}, \mathrm{kb}] ; \mathrm{k} \in \mathrm{R}^{+}
\end{aligned}
$$

In order to facilitate the process, verbal phrases and corresponding membership functions were extracted from previous studies and adjusted when appropriate. In the following, examples of verbal expressions used in many papers are provided. As can be seen, values are considered as distance and gray values. 
Table 1. Verbal phrases and corresponding gray distance numbers

\begin{tabular}{cccc}
\hline Importance & Verbal Phrases & Value & Verbal Phrases \\
\hline$[0.0-0.1]$ & Very low & {$[1-0]$} & Very weak \\
\hline$[0.1-0.3]$ & Low & {$[1-3]$} & Weak \\
\hline$[0.3-0.4]$ & Relatively low & {$[3-4]$} & Relatively weak \\
\hline$[0.4-0.5]$ & Average & {$[4-5]$} & Average \\
\hline$[0.5-0.6]$ & Relatively high & {$[5-6]$} & Relatively good \\
\hline$[0.6-0.9]$ & High & {$[6-9]$} & Good \\
\hline$[0.9-1.0]$ & Very high & {$[9-10]$} & Very good
\end{tabular}

Table 2. The results of weighting as well as the decision matrix

\begin{tabular}{ccc}
\hline Importance & Verbal Phrases & Deal \\
\hline$[0.0-0.1]$ & Very low & 1 \\
\hline$[0.1-0.3]$ & Low & 2 \\
\hline$[0.3-0.4]$ & Relatively low & 3 \\
\hline$[0.4-0.5]$ & Average & 4 \\
\hline$[0.5-0.6]$ & Relatively high & 5 \\
\hline$[0.6-0.9]$ & High & 6 \\
\hline$[0.9-1.0]$ & Very high & 7 \\
\hline
\end{tabular}

Table 3. Forming the decision matrix

\begin{tabular}{|c|c|c|c|c|}
\hline Matrix & Brand Loyalty & Brand equity & Brand Awareness & Perceived quality \\
\hline APPLE & 7 & 7 & 6 & 7 \\
\hline VAIO & 7 & 6 & 7 & 7 \\
\hline SAMSUNG & 5 & 5 & 6 & 5 \\
\hline LENOVO & 5 & 5 & 5 & 5 \\
\hline ASUS & 5 & 4 & 3 & 3 \\
\hline TOSHIBA & 3 & 4 & 3 & 4 \\
\hline AISER & 3 & 2 & 2 & 3 \\
\hline MSI & 3 & 2 & 3 & 3 \\
\hline $\mathrm{HP}$ & 4 & 4 & 4 & 4 \\
\hline DELL & 4 & 5 & 4 & 4 \\
\hline Criteria Direction & The greater the better & The greater the better & The greater the better & The greater the better \\
\hline Criterion Weight & 0.21101 & 0.278458 & 0.293527 & 0.217005 \\
\hline
\end{tabular}

In the current study, the gray data analysis was used to rank brands of Iran's laptop market.

\section{RESULTS}

In this section, the results of the data analysis will be discussed. The following table presents the decision making and other results. Four criteria were weighted and ranked using the Shannon entropy approach. The results of weighting as well as the decision matrix are presented in the following table. The values in the table are defined as shown in Table 2.

After forming the decision matrix, normalization is performed as shown in Table 3.

The grey data analysis results are as shown in Tables 4-7. 
Dutch Journal of Finance and Management, 1(2), 41

Table 4. Normalization

\begin{tabular}{lcccc}
\hline Scale-less Matrix & Brand Loyalty & Brand equity & Brand Awareness & Perceived quality \\
\hline APPLE & 1 & 1 & 0.8 & 1 \\
\hline VAIO & 1 & 0.8 & 1 & 1 \\
\hline SAMSUNG & 0.5 & 0.6 & 0.8 & 0.5 \\
\hline LENOVO & 0.5 & 0.6 & 0.6 & 0.5 \\
\hline ASUS & 0.5 & 0.4 & 0.2 & 0.2 \\
\hline TOSHIBA & 0 & 0.4 & 0 & 0 \\
\hline AISER & 0 & 0 & 0.2 & 0 \\
\hline MSI & 0 & 0 & 0.4 & 0.25 \\
\hline HP & 0.25 & 0.4 & 0.4 & 0.25 \\
\hline DELL & 0.25 & 0.6 & & \\
\hline
\end{tabular}

Table 5. Defining the reference objective series

\begin{tabular}{lcccc}
\hline Reference Objective series & Brand Loyalty & Brand equity & Brand Awareness & Perceived quality \\
\hline APPLE & 0 & 0 & 0.2 & 0 \\
\hline VAIO & 0 & 0.2 & 0 & 0 \\
\hline SAMSUNG & 0.5 & 0.4 & 0.2 & 0.4 \\
\hline LENOVO & 0.5 & 0.4 & 0.8 & 0.5 \\
\hline ASUS & 0.5 & 0.6 & 0.8 & 1 \\
\hline TOSHIBA & 1 & 0.6 & 1 & 0.75 \\
\hline AISER & 1 & 1 & 0.8 & 1 \\
\hline MSI & 1 & 1 & 0.6 & 0.75 \\
\hline HP & 0.75 & 0.6 & 0.6 & 0.75 \\
\hline DELL & 0.75 & 0.4 & &
\end{tabular}

Table 6. The gray relation coefficient effect

\begin{tabular}{lcccc}
\hline Coefficient defect & Brand Loyalty & Brand equity & Brand Awareness & Perceived quality \\
\hline APPLE & 1 & 1 & 0.666667 & 1 \\
\hline VAIO & 1 & 0.666667 & 1 & 1 \\
\hline SAMSUNG & 0.444444 & 0.5 & 0.666667 & 0.444444 \\
\hline LENOVO & 0.444444 & 0.5 & 0.5 & 0.444444 \\
\hline ASUS & 0.444444 & 0.4 & 0.333333 & 0.285714 \\
\hline TOSHIBA & 0.285714 & 0.4 & 0.333333 & 0.347826 \\
\hline AISER & 0.285714 & 0.285714 & 0.285714 & 0.285714 \\
\hline MSI & 0.285714 & 0.285714 & 0.333333 & 0.285714 \\
\hline HP & 0.347826 & 0.4 & 0.4 & 0.347826 \\
\hline DELL & 0.347826 & 0.5 & 0.4 & 0.347826
\end{tabular}

Table 7. The gray relation rank

\begin{tabular}{|c|c|c|c|c|}
\hline Rank & Brand Loyalty & Brand equity & Brand Awareness & Perceived quality \\
\hline APPLE & 0.21101 & 0.278458 & 0.195685 & 0.217005 \\
\hline VAIO & 0.21101 & 0.185639 & 0.293527 & 0.217005 \\
\hline$\overline{\text { SAMSUNG }}$ & 0.093782 & 0.139229 & 0.195685 & 0.096447 \\
\hline LENOVO & 0.093782 & 0.139229 & 0.146764 & 0.096447 \\
\hline ASUS & 0.093782 & 0.111383 & 0.097842 & 0.062001 \\
\hline TOSHIBA & 0.060289 & 0.111383 & 0.097842 & 0.07548 \\
\hline AISER & 0.060289 & 0.079559 & 0.083865 & 0.062001 \\
\hline MSI & 0.060289 & 0.079559 & 0.097842 & 0.062001 \\
\hline HP & 0.073395 & 0.111383 & 0.117411 & 0.07548 \\
\hline DELL & 0.073395 & 0.139229 & 0.117411 & 0.07548 \\
\hline
\end{tabular}

Table 8. Final score according to the gray relation rank

\begin{tabular}{cl}
\hline Results & Score \\
\hline VAIO & 0.907181 \\
\hline APPLE & 0.902158 \\
\hline SAMSUNG & 0.525143 \\
\hline LENOVO & 0.476221 \\
\hline DELL & 0.405515 \\
\hline HP & 0.377669 \\
\hline ASUS & 0.365009 \\
\hline TOSHIBA & 0.344994 \\
\hline MSI & 0.299692 \\
\hline AISER & 0.285714 \\
\hline
\end{tabular}

Brands are ranked as shown in Table 8. 
The above conclusion is based on the gray data analysis according to verbal variables. Based on the above conclusion, it could be stated that VAIO laptops have higher value and credit than other brands in Iran's market. This brand has the largest market share as well.

\section{CONCLUSION}

The present made an attempt to rank the existing brands on Iran's laptop market, laptop Iran using the gray data analysis on the basis of verbal variables. The use of verbal variables for such research is very useful because they are so structured to be associated with the minds of respondents. In fact, such variables help respondents provide better comparisons. The results indicated that VAIO is the leading brand in Iran's laptop market. In fact, the brand has the largest share of the laptop market, and according to Aaker's model criteria, it is considered most valuable brand in the laptop market.

\section{REFERENCES}

Aaker, D. A. (1996). Measuring brand equity across products and markets. California management review, $38,103$. https://doi.org/10.2307/41165845

Atilgan, E., Aksoy, S. and Akinci, S. (2005). Determinants of the brand equity: A verification approach in the beverage industry in Turkey. Marketing intelligence \& planning, 23, 237-248. https://doi.org/10.1108/02634500510597283

Budac, C. and Baltador, L. (2013). The Value of Brand Equity. Procedia Economics and Finance, 6, 444-448. https://doi.org/10.1016/S2212-5671(13)00161-5

Crocker, K. E. (1986). The influence of the amount and type of information on individuals' perception of legal services. Journal of the Academy of Marketing Science, 14, 18-27. https://doi.org/10.1007/BF02721812

Fornell, C. (1983). Issues in the application of covariance structure analysis: A comment. Journal of Consumer Research. pp. 443-448. https://doi.org/10.1086/208938

Jinfeng, W. and Zhilong, T. (2009). The impact of selected store image dimensions on retailer equity: Evidence from 10 Chinese hypermarkets. Journal of Retailing and Consumer Services, 16, $486-494$. https://doi.org/10.1016/j.jretconser.2009.08.002

Ratnatunga, J. and Ewing, M. T. (2009). An ex-ante approach to brand capability valuation. Journal of Business Research, 62, 323-331. https://doi.org/10.1016/j.jbusres.2008.04.003 